Studia Judaica 21 (2018), nr 1 (41), s. 97-116

doi:10.4467/24500100STJ.18.006.9176

Sabina Giergiel

\title{
The Saving Narratives of Daša Drndić
}

\begin{abstract}
The starting point for this paper is the assumption that by obsessive revisiting the events of World War II, the Croatian writer Daša Drndić attempts to influence indirectly the present. It parallels her narrators' declarations who-with a great dose of probability—can be simultaneously read as her alter egos. Hence, the article investigates and describes the strategy whose main aim is to retain memory about the past. In Drndić's texts this function is achieved through the acts of archiving, writing down, and grouping. These acts constitute non-standard ways to enhance the literary text with, for example, whole pages filled with the victims' names (integrated within the text or acting as a peculiar supplement to the volume).
\end{abstract}

Keywords: Croatian literature, Holocaust, memory, archives, children, ethics.

Daša Drndić (1946-2018) is a Croatian author who has become better known in her native land since the late 1990s. She owes her Croatian renown to two predominantly autobiographical perspective texts: Marija Czestochowska još uvek roni suze ili umiranje u Torontu [Maria Częstochowska Still Shedding Tears, or Dying in Toronto $]^{1}$ and Canzone di guerra: Nove davorije [Canzone di guerra: New Japes]. ${ }^{2}$ Her virtual absence from Croatian literary discourse until the 1990s can be explained by the fact that from 1953 to 1992 she lived, studied, published, and worked in Belgrade, only occasionally contributing to Croatian newspapers. As a result of the events of the 1990s (the growth of nationalism and the outbreak of a fratricidal war), she decided to leave Serbia for Croatia,

${ }^{1}$ Daša Drndić, Marija Czestochowska još uvek roni suze ili umiranje u Torontu (RijekaZagreb, 1997).

2 Daša Drndić, Canzone di guerra: Nove davorije (Zagreb, 1998). 
where she lived for the next three years. Having received a scholarship from the Canadian government in 1995, she went to Toronto and then settled in the Croatian town of Rijeka in 1997.

Since the 1990's, Drndic has published books in which she moves from a personal to a universal perspective, incorporating Holocaustrelated topics in such works as Totenwande: Zidovi smrti [Totenwande: The Walls of Death], ${ }^{3}$ Leica format: Fuge [Leica Format: Fuges], ${ }^{4}$ Sonnenschein: Dokumentarni roman [Sonnenschein: A Documentary Novel], 5 and April u Berlinu [April in Berlin]. ${ }^{6}$ All the works of this Croatian prose writer-despite their multitude of plots and the mosaic-like structure of the texts-are intrinsically coherent, centering around several key topic areas, the most basic and general of which is the experience of exclusion. In her two latest books-I am referring here to Belladonna, published in 2012, and EEG in 2016- the theme of the Holocaust appears fleetingly, moving aside to provide space for ruminations on contemporary times, more precisely, on life in Croatia.

This practically obsessive return to events from the past that are both traumatic for individuals and for whole societies (she is primarily interested in the World War II period) is characteristic of Drndić's reflections, and there are, in my opinion, two underlying reasons for her change. The first is the conviction that people today are obliged to remember-in particular, to remember those unknown and "weak" victims, ${ }^{7}$ with a sense of responsibility. Drndić consistently places the importance of microhistory over that of great historical syntheses. ${ }^{8}$ This probably stems from her conviction that individuals who are of no importance for key civilizational changes are actually mere splinters of great narratives and are thus absent from

${ }^{3}$ Daša Drndić, Totenwande: Zidovi smrti (Zagreb, 2000).

${ }^{4}$ Daša Drndić, Leica format: Fuge (Zagreb, 2003).

${ }^{5}$ Daša Drndić, Sonnenschein: Dokumentarni roman (Zaprešić, 2007). Polish edition: Sonnenschein: Powieść dokumentalna, trans. Dorota Jovanka Ćirlić (Wołowiec, 2010).

${ }^{6}$ Daša Drndić, April u Berlinu (Zaprešić, 2009).

7 The term "weak" individuals or heroes refers to characters who were not remembered by official historical discourse, do not exist in the collective memory, and whose lives and fates may seem unimportant from the community's point of view. The concept has been borrowed from Magdalena Dyras, Re-inkarnacje narodu: Chorwackie narracje tożsamościowe w latach dziewięćdziesiatych XX wieku (Kraków, 2009), who in turn adopted it from the work of Julijana Matanović, Krsto i Lucijan: Rasprave i eseji o povijesnom romanu (Zagreb, 2003), 130.

${ }^{8}$ I use here the contrast between the two as mentioned by Ewa Domańska in the context of her work, see Ewa Domańska, Mikrohistorie: Spotkania w międzyświatach (Poznań, 2005). 
our memory. Therefore, by asking indirectly how to save those who are already gone, Drndić suggests through her works that this can be achieved only by restoring the memory of a specific, singular person, someone who has a name, surname, and a unique story, thus bringing them out of the formless mass of humanity. People are forgotten only when their names are forgotten-or so maintains the narrator of the novel Belladonna, recalling a saying by Gunter Demnig9: "For every name carries a story and history predominantly remembers the names of criminals, forgetting the names of the victims." ${ }^{10}$ Through her texts, Drndic prevents the reduction of a person (whether dead or alive) to a number because "murder became possible when an individual turned into a number, when people's uniqueness was taken from them."11

The second reason for her repeated return to dramatic events from the period of World War II (this reason is considered here separately, although it remains closely connected with the first reason described above) rises from the conviction that the present does not function in a vacuum and that reality consists of parallel histories that-despite being sometimes separated by decades - create a network of connections and mutual influences. The perspective that unifies both temporal planes is clearly visible in the following thought, which in actuality is a self-referencing intrusion: "While writing, something that seems confined to the past becomes present through writing about it. Often when writing about an apparent past event, it is the present which is being written about." 12 Therefore, the past constantly haunts the present, just as the specters of victims constantly haunt this Croatian writer. ${ }^{13}$

Particularly among artists, contemporary reflection over the Shoah involves authors searching for their own creative paths; it also means attempting to answer the question of how to speak about a past which they have not personally experienced, and which-of possibly greatest importance—carries such enormous potential for trauma. Drndić has developed

${ }^{9}$ Daša Drndić, Belladonna (Zaprešić, 2012), 235.

${ }^{10}$ Daša Drndić, EEG (Zaprešić, 2016), 235.

11 Jasna Lukić, "Bol pamćenja i bol zaborava: (anti)povijesni romani Daše Drndić," Tré́a 12 (2010), 2:27, http://zenstud.hr/wp-content/uploads/2017/01/Treca_br2_2010.pdf [retrieved: 20 July 2017].

${ }^{12}$ Drndić, EEG, 213.

13 The term "haunting" unequivocally refers to the thanatological lexicon or, to be more precise, to "spectro-ontology," which is an obvious association during reflections over the Shoah. Aleksandra Ubertowska, "Rysa, dukt, odcisk (nie)obecności: O spektrologiach Zagłady," Teksty Drugie 2 (2016), 102-121. 
a way of writing about the Holocaust that is original and semantically rich and whose constitutive element mixes documentary and fiction-all of which will be discussed in detail later in this article. The author speaks in her own name, as an individual, relaying secondary testimony-she is indirectly marked by the Holocaust, which she knows from iconography and a broadly understood culture. Additionally, her personal experiences put her among people marked out as other, unwanted, and stigmatized. She also touches in her reflections upon the spheres of collective forgetfulness: the areas that are neglected, misrepresented, or excluded; the uncomfortable topics that become taboo. This context adds significance to a fragment of reflections from the author's visit to a famous villa on Lake Wannsee:

Shame? In the name of the past, in the name of the present, in the name of those known and unknown, in the name of the country whose passport I hold, in whose language I dream. Nausea caused by crimes committed also in my name. Is it normal? Not normal? ${ }^{14}$

The Croatian perspective, underlined many times (likely present also in the above quotation) and extremely significant in the context of the Holocaust perpetrated on the territory of Yugoslavia, ${ }^{15}$ results in an ethical obligation to remember. This obligation is doubled by specifying the conditions in which she writes and the place from which she speaks-a place clearly marked by the Shoah.

In discussing Drndić's works the attempt to create "a community of memory" can also be explored. "Community of memory," according to Alan Milchman and Alan Rosenberg, is directed toward the future and rather than commemorating, it serves future transformations; its version of history offers criticism instead of putting up monuments. The community of memory proposed by scholars tends to problematize rather than sacralize the past. ${ }^{16}$ When considering the works of this Croatian

${ }^{14}$ Drndić, April u Berlinu, 24.

${ }^{15}$ I mean here the infamous role played during the "Final Solution of the Jewish issue" by the puppet state of NDH (Independent State of Croatia), proclaimed after the capitulation of Yugoslavia in 1941 and subordinated to Hitler. The ill-famed Jasenovac camp was on the NDH territory.

${ }^{16}$ According to the authors, the concept of the "community of memory" was borrowed from Edith Wyschogrod. See Edith Wyschogrod, "Man-Made Mass Death: Shifting Concepts of Community," Journal of the American Academy of Religion 58 (1990), 2, quoted in: Alan Milchman, Alan Rosenberg, Eksperymenty w myśleniu o Holocauście: Auschwitz. Nowoczesność i filozofia, trans. Leszek Krowicki, Jakub Szacki (Warsaw, 2003), 118. 
author, it must be underlined that she stresses the falsity and-above all-the harmfulness of a monumental version of history which sacralizes the nation and to this end controls and limits the recollection of the past, by marginalizing all information that could undermine the constructed, unequivocally positive image of the past. In practically all of her texts, Drndić reviles attempts at affirming the NDH (Independent State of Croatia). In addition, she criticizes the erasure of all traces of the involvement of public figures during World War II and stresses the disgraceful activities of certain members of Croatian clergy at that time. She also argues that group identity should form and determine itself not only in relation to significant events from national history but also-significantly in Croatia-in relation to the Holocaust, which is a subject that has been marginalized, omitted, or displaced.

Drndić's two most recent books clearly depart from a formula dominated by the topic of the Shoah. In Belladonna, she focuses on Croatian contemporary life, on the condition of its society, and on the fate of an individual considered detritus by a consumerist society, from the point of view of the experiences of an old, ailing person. In $E E G$, it is difficult to determine a main theme. However, in both texts the Holocaust is evoked multiple times, and it still constitutes one of the major themes of Drndić's books. The events of World War II continuously reappear in her texts, and the Shoah exists on a "historicity-obliterating trajectory" 17 as if the passing of time (with its forward motion) were connected to the circular returning of what is fundamental. In accordance with philosophers' and scholars' expectations, the Holocaust is thought to be a particular injury, a never-healing, metaphorically understood wound in culture. For Drndić, it constitutes an event that she carries inside her, which haunts and does not allow her to forget. Particularly symptomatic here is a fragment from the text April in Berlin, in which the author recollects her stay in Germany and Austria:

All the time, from the beginning to the end of my stay in Berlin, I was followed by history gone mad, screaming "Listen! Look!" It arose as a vapour from the Berlin lawns around Lake Wannsee, from tarmac boulevards, from monumental buildings, from elegant department stores; as a velvet ribbon from shop displays, it danced on my interlocutors' exhalations, injected its lethal aroma under my skin and ... covered (my) Berlin sky. ${ }^{18}$

17 Aleksandra Ubertowska, Holokaust: Auto(tanato)grafie (Warsaw, 2014), 49.
18 Drndić, April u Berlinu, 109. 
This is the history from which the author cannot free herself and which persecutes her, making any rest impossible in Vienna too:

Even before I arrived in Vienna, where I was to spend two winter months, I planned that I would see the places which Bernhard had visited and would have casual small conversations with him ... Then, on my way to meet Bernhard ... as I was passing the Court Theatre and Heldenplatz, I heard this frightening chanting Sieg heil!, Sieg heil! $!^{19}$

What is predominantly visible in fragments of this kind is the elimination of distance in time, in which events from the past are superimposed on the present, thus indicating that temporal relations are of primary importance to her.

\section{The Form}

The works of Drndić often have a mosaic-like, polyphonic structure with some fragments even coming close to essayist discourse (according to Aleksandra Ubertowska, such discourse in Holocaust literature has the status of a rather marginal utterance, threatening the basics of the ethics of representation), ${ }^{20}$ making it possible for the author to mix temporal planes in order to connect reflections on the past with a contemporary point of view and to include fragments of autobiographical narration interspersed with metatextual inclusions. The fragmentary character of this prose is evident both on the level of the whole text (as Drndić's novels often start at an arbitrarily chosen moment, from a certain microhistory, and end in an equally accidental way, often with a clear sign that this particular text is a fragment of a greater whole $)^{21}$ and on the level of structure (I mean

${ }^{19}$ Ibid., 114.

${ }^{20}$ Ubertowska, Holokaust: Auto(tanato)grafie, 19.

${ }^{21}$ The text Canzone di guerra: Nove davorije (a digital version of the book is available at https://elektronickeknjige.com/biblioteke/online/canzone-di-guerra/ [retrieved: 20 July 2017]) ending with the telltale words "It is not the end" ("nije kraj"). From the perspective of genre theory, openness is represented by a fragmentary structure, interrupted narration, and the mentioned open ending. This can be understood as a formal device hinting at resistance against the classical ways of storytelling, indirectly indicating that the problem of exclusion is eternal and the story just told does not exhaust this topic; it can be also considered an announcement of books to come in which the same motifs will reappear. This is the context that Andrea Zlatar uses to decode the ending of another Drndićs text; she maintains that the cycle which begins with the novel Canzone di guerra will be continued; more importantly, the ending "That's not all" ("ima još") of her next novel, Totenwande: Zidovi smrti, points out that according to the author the eponymous "walls of death" constantly 
here creating narration by recalling seemingly unconnected episodes which, when perceived all together, form a kind of a unity, ideologically superordinate). It also appears that the fragmentation principle applied by the writer reaches beyond the framework of the poetics of an individual text. The connections between particular works, placing the existing books in new (con)texts, and the circulation of motifs and characters give the reader an impression that each text created by Drndic is a peculiar kind of fragment, and the deep meaning of her creative output can only be read by people confronting the individual texts, "individual cases" which allow us to piece together the diagnosis of the world that the author proposes.

In her last book, Drndić tries to describe the features of her writing through the words of the narrator. In $E E G$ she includes a metaliterary comment: "[w]hat I am writing is neither a diary nor a travelogue nor a novel; it is something in between, this crippled, handicapped jumping through condensed time, through the particles of time that got detached from each other and swim in the tunnels of the present."22 This fragment clearly indicates that the author's reflection concerns events and personal stories that exceed their timeframes and whose specificity makes them appear still active and able to influence the present by living and resonating within it. Drndić maintains that the Holocaust is one such event which abides in time and should not be subjected to any treatment aimed at removing it and confining it to the past. ${ }^{23}$ In this context, the technique used in $E E G$ is very symptomatic. Evoking the artistic technique of Shimon Attie, which involved superimposing photographs from the time of World War II onto the contemporary façades of Berlin buildings, Drndić evokes images from the past in which they are confronted with Zagreb's presence. This technique is based on describing today's view of a street or a single building (the author uses synesthesia in such fragments by evoking the smells and sounds of contemporary Zagreb) by confronting it with an image from its past; in the center of such an image is a Jewish family or a single person who used to live or work in the described building. In this way

rise around us. Andrea Zlatar, Tekst, tijelo, trauma: Ogledi o suvremenoj ženskoj književnosti (Zagreb, 2004), 148.

${ }^{22}$ Drndić, EEG, 221.

${ }^{23}$ It converges with the moral imperative of Frank Ankersmit, who thinks that the Holocaust is the one event in the history of humanity that should remain-marked by melancholy—in the eternal now. Frank R. Ankersmit, "Pamiętając Holokaust: Żałoba i melancholia," trans. Andrzej Ajschtet, Andrzej Kubis, Justyna Regulska, in id., Narracja, reprezentacja, doświadczenie: Studia z teorii historiografii, ed. Ewa Domańska (Kraków, 2004), 403-426. 
the past breaks into the present; however, as the Croatian author states, "the past cannot return because it does not go anywhere; one just needs to find a proper link connecting it with what is now and what is to come."24

The prose texts of Drndić exist therefore as a kind of replacement testimony, and the author herself accepts the burden of testifying and rescuing from oblivion. She can be thus described as a "truth carrier" (the concept of a Geheimnisträger).$^{25}$ Yet in Drndić's case, the specifics of this attitude do not involve personification of historical truth (someone who has gone through hell and carries it within themselves, as for example Primo Levi) but instead is its transmitter and guardian. In the opinion of Aleksandra Ubertowska, the condition of a truth carrier is associated with a certain displacement, by meekly confessing to one's own insignificance in the face of the complexity of the story that is to be told (or, in Drndić's case, often just recalled) and which should remain and survive its bearer. ${ }^{26}$ Such displacement or even removal of one's own person to the background, thereby subordinating oneself to the story being told, is particularly evident in texts where the main topic is the Holocaust. This autobiographical element is clearly present in Drndić's books, yet in individual texts it is either a dominant feature or it moves to one side to allow space for the tale of important Others. Her literary output is characterized by the varying tensions between autobiographical discourse and objective discourse (which in certain fragments is very dry and approaches historiography). However-and this must be stressed-the factual parts are usually complemented by emotional tones. The structure of these texts is unbalanced, as exemplified in April in Berlin and especially in Totenwande: The Walls of Death where the author's subject is removed to the background, and her (dramatic) experiences are overshadowed. Autobiographic motifs are present in these novels, yet they seem to give way to history, which should not be obscured by what is individual. The flow of the argument is jagged, fragmentary, as if it were reflecting the meandering of thoughts while microhistories that are the told, rewritten or evoked aspire to the fantasy of fullness and completion. I think it would not be inappropriate to conclude that the form chosen by the author is

${ }^{24}$ Drndić, EEG, 323.

${ }_{25}$ This term is used by Ubertowska to describe Primo Levi's attitude. The reflections of this Polish writer are for me very inspiring, although of course I realize the fundamental difference between Levi's and Drndić's situations. Ubertowska, Holokaust: Auto(tanato)grafie, 47-48.

26 Ibid., 48. 
a kind of protest against the oppression of finiteness, questioning every rigid project-in this case a project is understood as a set of rules used to assign a category from genre theory to the text.

Drndić's style of writing can be described as the poetics of fragment, from which emerges a project of individual resistance against all forms evoking institutionalized wholeness. The dispersion of thoughts is, however, only apparent, as her books are written with a conviction about the value of individual resistance against evil, illustrated by multiple examples from different times and places. The anarchistic way of thinking involving the need to question and to stand outside prevents overlooking alarming signals (due to acclimatization or conformism) or failing to notice them in time. She seems to believe that the contemporary reader needs to be shaken or at least strongly stirred, for obviousness-identified with a fossilized, predictable form-is tantamount to reader comfort. In her opinion, such comfort is offered by the exhibition that can be seen in the villa at Lake Wannsee:

[This exhibition] wants visitors to be educated and informed but by no means shaken; in no way does it want to awaken in them the merry fiendish company of the fallen angels of the world. The reader leaves this villa without remembering anything because the memory that the exhibition offers is raddled with a monotonous rhythm and faded colors. The exhibition in the villa at Lake Wannsee is a total/ finished exhibition, and any project like it brings the story to an end or, if one likes, offers a final solution. The curators of the memorial exhibits are worried about their guests and do not want their visitors to get excited-well, perhaps just a little to speed up their circulation a tad, such as occurs during gentle exercises for the disabled and the old. ${ }^{27}$

Institutionalized forms of memory and collective commemorative practices are also subject to inevitable fossilization-which is why Drndić devotes so much space in her books to so-called counter-monuments. Such practices blind people to the vision of individuals, and the Croatian author thinks it is individuals who are worthy of being remembered. ${ }^{28}$ This is why she constantly gathers other people's stories ${ }^{29}{ }^{29}$ thereby collecting

${ }^{27}$ Drndić, April u Berlinu, 23.

28 These thoughts are inspired by Aleksandra Ubertowska's reflections on the book Minima moralia by Theodore W. Adorno; see Aleksandra Ubertowska, Świadectwo - trauma - głos: Literackie reprezentacje Holokaustu (Kraków, 2007), 32-33.

${ }_{29}$ The notions such as "other people's stories" / "foreign" stories or "mediated experience" are unambiguously associated with the category of postmemory. It is worth noting that the issues connected to forwarding of the generation trauma also appear in Drndićs 
the fates of others, which are then transformed into literary subject matter and-still in a quasi-documentary form-are placed in her works.

Dorota Krawczyńska aptly notes the following in reference to Holocaust literature:

Communing with this literature requires the act of distancing oneself. The distance, or the constant consciousness of the separation between oneself and the suffering character is the basic element of the concept of empathy, underlined in the characteristics of this emotion by Martha Nussbaum. ${ }^{30}$

If the authors writing about such dramatic events are unable to transmit them adequately, they are forced to look for alternative ways of translating the tragic experiences into literary subject matter. This also can explain the formal means used by Drndić in her prose. If it is impossible to convey a suffering person's experience in the form of a traditional story without identifying with them unnecessarily (or maybe even without empathizing with them undesirably), an attempt must be made to create a different way of recording this experience. The author thus gives voice to the characters in her prose and objectively suspends the voice of the author/narrator. As a consequence, the tale of the "victim" is presented unadulterated and deprived of an (in)direct author's commentary. By so doing an autonomous, strongly expressive form of communication is made possible, free from attempts to charm the reader whether through tricks proving the writer's talent or through narrators who possess the knowledge of how to create an attractive narrative. The silencing of one's own voice and the author's stepping back seem to be in this situation a defense against

[t]aming the otherness by grabbing it, by ... imperial appropriating it or by ... identifying with another person through fraudulent usurpation, encroaching on one's autonomy. This danger is particularly threatening when compassion is identified solely with the projection of one's own "I" and with applying the rules, the stereotypes of feeling or intellectual-emotional understanding of "the other," which still is done according to one's own rules. ${ }^{31}$

In her books, especially those concerning the Holocaust, Drndić gives voice to those who cannot speak (as they are most often dead). In addition,

works. In my opinion, however, they require a detailed analysis. Consequently, here I only signalize their presence.

${ }^{30}$ Dorota Krawczyńska, "Empatia? Substytucja? Identyfikacja? Jak czytać teksty o Zagładzie?," Teksty Drugie 5 (2004), 182.

${ }^{31}$ Anna Łebkowska, "O pragnieniu empatii w prozie polskiej końca XX wieku," Teksty Drugie 5 (2002), 160, quoted in: Krawczyńska, "Empatia?, Substytucja?”, 184. 
as she constructs both the characters' utterances, her own narration on the basis of authentic sources or the knowledge of facts, she creates a new quality that unites authentic testimony with fiction. Her books seem to be eloquent proof that history and literature are not antagonistic phenomena and that they can be unified in one text. What is more, when memory (which is the domain of subjectivity, uniqueness, and non-continuity) and historiography (connected with assumed unequivocal meaning, finiteness, and rationality) interpenetrate, a new invaluable intellectual and cognitive whole is thus created. ${ }^{32}$

\section{Catalogues}

The obsession of cataloguing and of recalling through formal discourse the forgotten (especially the forgotten victims) is a characteristic feature of Drndić's works. In $E E G$ we read:

I now fanatically, nearly obsessively—although this burdens literature, and is thus unnecessary-evoke the names of people because I see with growing clarity that maybe these names are the last bit of a spider's web that makes them stand out in the ubiquitous chaos of the world. ${ }^{33}$

If any individual represents a certain story, and such a story must be supported by proofs to be recognized as true, then Drndić continuously returns to numbers, names, dates, and biographical data. The fragments of her books where the cataloguing aspect becomes dominant create a sort of mini-archive: an archive that primarily preserves victims' names and their testimonies-mediated by the author-about the departed, but also factual notes about those who were on the opposing side (in EEG such a function is fulfilled by several pages filled by a list of Latvian Nazis, some of whom found safe haven after the war within the structures of the American CIA). ${ }^{34}$ The archive itself reveals its ambivalent structure

${ }^{32}$ This fragment (the last paragraph of this part) appeared in my book: Sabina Giergiel, Ocalić pamięcią: Praktyki pamięci i zapominania we wspótczesnej prozie postjugostowiańskiej (Opole, 2012), 208-209. An exhaustive description of juxtaposing literature and historiography, with presentation of the views of the two most renowned supporters of such opposition, can be found in the text by Katarzyna Chmielewska, "Literackość jako przeszkoda, literackość jako możliwość wypowiedzenia," in Michał Głowiński, Katarzyna Chmielewska, Katarzyna Makaruk, Alina Molisak, Tomasz Żukowski (eds.), Stosowność i forma: Jak opowiadać o Zagładzie? (Kraków, 2005), 21-32.

${ }^{33}$ Drndić, EEG, 28-29.

${ }^{34}$ Ibid., 167-180. 
especially in the context of the Holocaust. It is a symbol of an extensive bureaucracy, characteristic of every totalitarian regime, in particular the German administrative system, documenting all the stages of the "Final Solution." The archives formerly created in order to count, document, catalogue, and ultimately remove what were viewed as unnecessary people now are used by Drndić to save and prolong the memory of not only the victims but also about the victimizers. ${ }^{35}$ Such a dual function is served by, for example, the inclusion of a twenty-page-long detailed record of Jewish property seized by the Germans in Zagreb, contained in EEG. ${ }^{36}$ The cataloguing obsession also emerges during a grant-supported stay episode in Vienna, which the author records in her book April in Berlin. She includes the results of an investigation she carried out during her stay in the Austrian capital. In her own words she recounts how she was researching other people's lives. ${ }^{37}$ This involved photographing the house numbers where Jews used to live, which she then put in her book together with short, often incomplete biographies and photographs of these inhabitants. In the eye of the viewer, photography breathes life into what has been gone, what has left behind only an empty space. Thus these brief notes with accompanying photographs become the proof of existence of a life, filtered through what we know about the fates of these characters. The photographs in April in Berlin present pre-Shoah images and evoke the world of the Jewish middle class, a world extinguished by a disaster. These particular pieces of evidence of the existence of life are also a way of resurrecting individual people from oblivion. According to a wellknown phrase of Roland Barthes, a photograph immobilizes time, ${ }^{38}$ and it excavates from the past people whose traces are gone from the tissue of the city; thus again their existence is saved through the efforts of the writer. In her book, these sample pages are small pieces from a nonexistent album, an effect of the passion for collecting, accompanied by bitter reflections. The author openly asks: "But who would publish such an album? Even now people tell me that I torture them with these names,

${ }^{35}$ I used here the reflections of Marianna Michałowska on the work of Christian Boltanski. Marianna Michałowska, "Sztuka dokumentu - fotografia i trauma," in Tomasz Majewski, Anna Zeidler-Janiszewska (eds.), Pamięć Shoah: Kulturowe reprezentacje i praktyki upamiętniania, 2nd edition (Łódź, 2011), 747-757.

${ }^{36}$ Drndić, EEG, 302-321.

37 Drndić, April u Berlinu, 219.

${ }_{38}$ Roland Barthes, Światto obrazu: Uwagi o fotografii, trans. Jacek Trznadel (Warsaw, 1996). 
with enumerating, with cataloguing of those names; why are you so hooked on doing that, they say." 39

The imperative to give credibility to the narrated story is evoked expressis verbis in $E E G$, where one of the key motifs is an investigation of the death of a Latvian woman of Jewish origin, a youthful love of the narrator's mother's brother. On the basis of available documents and oral testimonies that he has managed to gather, he attempts to reconstruct the events. Yet the fate of the Jewish family remains unknown, and the information which he managed to obtain is fragmentary. This microhistory perfectly reflects the way the Croatian writer chooses to save her subjects from oblivion. Above all, in her concept of writing (which is synonymous with remembering) the imperative to document is of utmost importance. This peculiar type of investigation becomes a pretext to evoke dozens of names of Latvians involved in the Final Solution. As can be read in the book, the narrator has data about the number of trains from German-occupied territories which reached Latvian soil, about their schedule, the number of men and women transported as well as the ages of the children similarly transported and the general number of people who lost their lives in these transports. ${ }^{40}$ Yet he refrains from quoting these figures. "If I start to list all this, someone may think that I'm obsessed, ask why I'm so fixated on this and conclude that this is not literature, but an ordinary ... pamphlet. So, to avoid unsettling potential readers, I won't make lists." ${ }^{41}$ Such wariness probably stems from the experiences of the Croatian author, who in her country faced unfavorable comments regarding the topics of her work. She was advised that instead of boring her readers with the Holocaust, she ought to take up writing about her homeland and love. ${ }^{42}$ Alternatively, she was accused of ingratitude toward her own country. ${ }^{43}$ It is impossible not to notice in these author's comments a tone of abandonment combined with a feeling of isolation. The quoted utterances also prove indirectly the courage of the author, who clearly leaves herself open to accusations of standing against her community and decides nonetheless to break a commonly held taboo.

\footnotetext{
39 Drndić, April u Berlinu, 230.

40 Drndić, EEG, 189-190.

41 Ibid., 190.

42 Drndić, April u Berlinu, 54.

43 Drndić, EEG, 39.
} 


\section{The Children ${ }^{44}$}

Both Primo Levi and Giorgio Agamben devote much space in their reflections to the absolute witnesses who, according to them, are "the Muselmänner, $" 45$ those who did not survive. Thus we face the-impossible to mitigate and much evoked-aporia connected with the very presentation of the Holocaust. Its essence is that the only people who would be able to tell the truth of the story are dead and thus voiceless, while testimony of those awful events comes from the people who were not touched by absolute evil. ${ }^{46} \mathrm{~A}$ character often evoked in this context is a three-year-old child described by Levi (Hurbinek), whose speech was limited to a single, incomprehensible word. Maria Janion describes him as a witness without words, one of a number of figures representing the "integral witness." ${ }^{47}$ Not only do scholars studying the Holocaust but also those who survived the Holocaust point out the paradox inherent in the very act of giving testimony to these events. For absolute witnesses, those immersed-as Levi describes them-did not return, or if they did, they returned mute. ${ }^{48}$ Pseudo-witnesses (Agamben's term for those who survived) assume their role, giving testimony to the missing testimony. ${ }^{49}$ Drndić is not a survivor, yet considering the task she set for herself, she may be called such a witness. From the formal point of view, in Drndić's case it is justified by her extraordinary meticulousness and persistence in searching for traces left by the dead as well as her factual precision (which obviously is interwoven with fiction many times).

What seems to me extremely important in this context is the fact that in her texts about the Holocaust, Drndić devotes much space to children who were the victims of medical experiments. Children, those most

${ }^{44}$ This part of the article is a slightly modified section of my book: Giergiel, Ocalić pamięcia, 236-238.

${ }^{45}$ The Muselmänner (sing. Muselmann), i.e. "the Muslims," was a term in camp slang denoting prisoners emaciated by starvation who lost their will to live and became increasingly apathetic toward external stimuli; during selections in the camps they were usually sent to the gas chambers [translator's note].

${ }^{46}$ Pointing out the impossibility of the Holocaust, Giorgio Agamben writes that "the aporia of Auschwitz is, indeed, the very aporia of historical knowledge: a non-coincidence between facts and truth, between verification and comprehension." Giorgio Agamben, $C o$ zostaje z Auschwitz: Archiwum i świadek (Homo Sacer III), trans. Sławomir Królak (Warsaw, 2008), 9.

${ }^{47}$ Maria Janion, Żyjąc tracimy życie: Niepokojace tematy egzystencji (Warsaw, 2003), 397.

${ }_{48}$ Primo Levi, Pogrążeni i ocaleni, trans. Stanisław Kasprzysiak (Kraków, 2007), 100-101.

49 Agamben, Co zostaje z Auschwitz, 33. 
defenseless and vulnerable of beings, are for this Croatian writer integral witnesses, deprived of a voice. Their element is silence for several reasons: they experienced the ultimate evil and died (so they cannot speak and the writer to some extent takes the responsibility upon herself to speak about/for them), and even if just before death they were provided with the opportunity to speak, their communications vanished into the ether as the victims of the experiments in the Neuengamme camp were children of different nationalities; therefore, they were unable to communicate with each other, and words not understood are as close to silence as can be. In the book Totenwande, we read:

From Auschwitz to Neuengamme the children travelled by train. It was not a cattle wagon. They were looking at each other in silence. At some point Marek, Eleonora Witonska and Mania started crying. They were still very young. The greatest number of children, fourteen, came from Poland. It was easier for them as they could talk to each other. Wanda Junglieb, she from Yugoslavia, aged twelve, and Sergio de Simone, he from Italy, aged seven, could only look at one another. Alexander had his brother Eduard to whom he could say in Flemish: I'm scared. Jacqueline Morgenstern and Georges-André Kohn were inseparable and were an example of sad camp love. None of them spoke about themselves. All of them called out for their mothers. ${ }^{50}$

The last reason for their silence was connected with the fact that children probably were not as aware of the peril they were in as their adult counterparts. In this context their silence can be associated with the impossibility of representing their experience adequately, as the experience itself defies logic. Here again the child figure from the camp must be evoked-the boy Hurbinek as described by Levi. The need to speak and simultaneously the inability to speak makes him a mute witness who nevertheless speaks. Thus both Levi and Drndić take the position of a medium of sorts and provide a way of communicating for those who cannot testify themselves.

In Leica format Drndic recounts fictional tales of both the dead children and their torturers. The utterances of the victims of medical experiments are written in dry, fact-based, informative language. Drndić allows the dead to speak, in a way withdrawing herself beyond the framework of testimonies and surrendering her superordinate status within the story. This is a form of ethical gesture, connected to abandoning the temptation to narrate, resulting from the privileges that the institution of narrator/ author provides. It is worth adding that the stylized utterances of the

${ }^{50}$ Drndić, Totenwande: Zidovi smrti, 44. 
children through their fragmentary narrations together with the facts they recall (which include the names of the places in which the experiments were conducted, statistics, and biographical notes) create a kind of court transcript of a trial (which never happened). As Anera Ryznar aptly notes, the charge is brought in the names of the victims by the author. Yet her aim is not actually to point out the guilt of the Nazis and their collaborators (as commonly accepted) but rather to demonstrate that a part of scientific discoveries and the ensuing development of our civilization were built upon the foundations of crimes, on forgotten victims and upon evil that reaches far into the past, but which still is happening. ${ }^{51}$ Therefore, she is pointing an accusatorial finger at the whole of human civilization. To lend credence to these statements, Drndic quotes at the end of the book a "little, incomplete list of medical experiments conducted on people in the name of peace, democracy and the development of the human race," ${ }^{52}$ in which she chronologically enumerates information about American, Japanese, and German studies that took place mostly in the twentieth century (the last of the experiments evoked by the author took place in the year 2000). The list ends with a particularly pertinent question, printed in bold: "Have you remembered their names?" It appears again several pages later under the names of the architects who lost their lives in the first year of the war in Bosnia. The last sentence of the text suggests that contemporary people/society are/is not interested in such topics, as the answer to the author's question is "No, it was Saturday." 53

\section{Memory}

A testimony, a proof of existence, and a metaphorically understood salvation is a text (a story) where the data about a person and their history are written down. In this way Drndić provides her characters with eternal life. Writing about oneself and also about the nameless victims of Nazism such as, for example, Sergio de Simone ${ }^{54}$ is an act of restoring memory and

${ }^{51}$ Anera Ryznar, "Interdiskurzivne fuge u romanu Leica format Daše Drndić," https://www.academia.edu/9800687/Interdiskurzivne_fuge_u_romanu_Leica_format_ Da\%C5\%A1e_Drndi\%C4\%87 [retrieved: 21 July 2017].

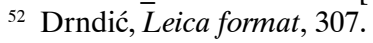

${ }^{53}$ Ibid., 315, 337.

${ }^{54}$ Sergio de Simone belongs to the group of children experimented on by German doctors. He appears in the book Totenwande and in the novel Leica format, where he is mentioned in passing. 
proof of how important these existences omitted in official discourse are. In this context, the words of Renate Lachmann seem important: she connects the act of remembering with a second act of naming. ${ }^{55}$ Such second naming can take the form of building a larger narrative from "weak" stories that contain not only the names and surnames of the heroes, but also fragments of their biographies, seemingly unimportant but bringing these characters closer to the audience, less abstract and equipped with features unique to each of them. The particular ethics of memory can be reduced to the duty of remembering, which approaches the imperative of justice and is a kind of reparation. The obligation to remember is juxtaposed here with the total Holocaust, completed by forgetting about its victims.${ }^{56}$ Remembering thus becomes a way of overcoming death, its particular negation, and at the same time is the repayment of a debt. For we are, as Paul Ricoeur maintains, "indebted to those who preceded us in what we are. The duty to remember is not limited to guarding the material traces ... but upholds the sense of obligation towards others about who can be said to be no longer here, although they used to be." ${ }^{57}$

One of Drndićs features is a particular version of fatalism; the writer seems to be convinced that the past, often in its negative aspect, can emerge where and when it is least expected because human iniquities have been repeated for centuries, and man does not develop ethical predispositions in parallel with civilizational development. The fate of immigrants to America from the early twentieth century, the Jews during World War II, postwar medical experiments on prisoners and developmentally delayed people, or the attitude of the citizens of the Western countries to newcomers from less developed parts of the world can be pointed at as a proof. The criticism of contemporary civilization appears expressis verbis especially in the fragment inspired by Walter Benjamin's analysis of Paul Klee's painting

${ }^{55}$ Renate Lachmann, "Mnemotechnika i symulakrum," trans. Artur Pełka, in Magdalena Saryusz-Wolska (ed.), Pamięć zbiorowa i kulturowa: Wspótczesna perspektywa niemiecka (Kraków, 2009), 297. The act of recalling their existence from oblivion equates here to a symbolical overcoming of death. Here the next words of Lachmann are extremely significant: "Imagines, simulacra (tropes) reverse forgetting, and raise the dead. The unfinished past gains meaning only through a caesura, disaster or a threat of being forgotten. This techne creates the mechanism of doubling, of re-praesentatio, the return to the presence of the absent." Ibid.

${ }^{56}$ Michał Kaczmarek, Proza pamięci: Stanistawa Vincenza pamięć i narracja (Toruń, 2009), 106-107.

${ }^{57}$ Paul Ricoeur, Pamięć, historia, zapomnienie, trans. Janusz Margański (Kraków, 2007), 118. 
Angelus Novus (Angel of History). In Drndić's version, contemporary society obsessively follows new technological developments. As a result, the human mind, stretched to its limits with all the data, numbers, and codes which are necessary to live, has no chance of remembering what is really worth remembering. By juxtaposing the gigantic collection of numbers which we are forced to remember with a single number on the arm of a child victim of Nazi experiments, Drndić (in reference to a poem by Wisława Szymborska) maintains that to remember that particular row of digits is the duty of every human. This will be a proof of sorts of the existence of this poor boy, forgotten by history as are many other nameless victims. ${ }^{58}$

In Sonnenschein, the author included an extremely long list of names of Jews deported or killed in Italy between 1943 and 1945. Here enumeration is a technique that de-automates the reception as well as serving as an ethical gesture. ${ }^{59}$ This list takes up almost eighty pages and can be understood as a particular measure dictated by the intention to protect them from oblivion. The list of names becomes a form of a prosthetic for experience and memory. ${ }^{60}$ The pages in which in three columns the names and surnames of murdered people are placed by Drndić, disquiets and discommodes the reader. It appears to me that the cataloguing process, the figure of enumeratio, involving the dry listing of the victims of Nazism name after name without any commentary, speaks to the reader more strongly than an aesthetically shaped tale of the crime. Drndic fights

${ }^{58}$ Drndić, Leica format, 42. A fragment of Szymborska's poem connected with reflections on the duty to remember appears also in the next book by Drndić, published several years later (see April u Berlinu, 245). How relevant nowadays such reflections are can be confirmed by the fact that the comment from Leica format "and new numbers are still coming" is accompanied in April u Berlinu by the toponym "Srebrenica."

${ }^{59}$ A similar technique is used by Vladimir Todorović in his historiographical book Poslednja stanica Aušvic. From pages 26-226 he cites the names of Jewish victims from Vojvodina. This list was prepared by a joint committee of the Serbian Academy of Sciences and the Hungarian Academy of Sciences. The author selected from it the names of persons who declared themselves as Jewish. Beside the names, information (whenever there was any) was included regarding profession, age, place of residence, year of birth and death, and finally the place of death (which in this case was always Auschwitz). Explaining the meaning of this, Todorović remarks that scholars usually omit the names of the victims or place them at the end of their books. In his opinion, the victims deserve a more prominent place as they were the reason for the research. Vladimir Todorović, "Objašnjenje," in id., Poslednja stanica Aušvic: Batschka 1944. Judenrein (Novi Sad, 2015), 23-24.

${ }^{60} \mathrm{I}$ am quoting these words after Dominick LaCapra, who describes the role of an archive in historical research. See Dominick LaCapra, Historia w okresie przejściowym: Doświadczenie, tożsamość, teoria krytyczna, trans. Katarzyna Bojarska (Kraków, 2009$), 37$. 
for the remembrance of individual people; she opposes nameless sets of victims in which individual existence is lost. It is explicitly confirmed by the author's cry that accompanies her visit to the ill-reputed villa at Wannsee Lake, in which the Final Solution was sanctioned. Among the exhibits is a plan outlining the extermination of the Jews, prepared by the Nazis and consisting of the lists of European countries with the number of Jews who lived in them at that time. Drndić includes this ominous table in her book and adds her very significant comment right under it: "And where are the names, where are the names!" 61 In the novel Belladonna, the author focuses in turn on the fate of European Jews who, fearing for their lives, as early as 1939 began their journey to Palestine. As a result of a very harsh winter their escape from the Holocaust ended in the Serbian town of Šabac. In 1941 the majority of them died in mass executions, and the survivors were sent in 1942 to the Sajmište camp in Belgrade. ${ }^{62}$ The list of their names (1,055 entries) was placed in a pocket on the inside of the cover of Belladonna.

The memory of the Shoah remains in the author's mind like a thorn ${ }^{63}$ which does not stop irritating, forcing her to compile lists and catalogues and particular micro-scale encyclopedias of the dead. Drndić cannot free herself from this need and returns to the fragments of life she has already described, using again the crumbs of the same past. She does all this against the advice of her contemporaries who push away uncomfortable and unpleasant recollections. Unlike some of her compatriots, this Croatian author does not try to push away the splinter of memory "which opens ... for the suffering of another person, in an almost literary way causes pain from which many ... try to protect themselves." ${ }^{4}$

Analyzing the writings of Primo Levi, Ubertowska utilizes the deliberations of Jacques Derrida on the essence of testimony, which I find

${ }^{61}$ Drndić, April u Berlinu, 27.

${ }^{62}$ More on this topic: Gabriele Anderl, Walter Manoschek, Neuspelo bekstvo: Jevrejski "Kladovo-transport" na putu za Palestinu 1939-42, trans. Eva Timar (Beograd, 2004); Milica Mihailović, Branka Džidić, Kladovo-transport. Beograd, Šabac, Kladovo, 14-20. oktobar 2002 (Beograd-Šabac-Kladovo, 2002); Milica Mihailović (ed.), Kladovo transport: Zbornik radova sa okruglog stola (Beograd, 2006).

${ }^{63}$ I refer here to a fragment of the book by Emmanuel Lévinas, Inaczej niż być lub ponad istota, trans. Piotr Mrówczyński (Warsaw, 2000), 89. Dorota Głowacka comments its upon in the following way: "For the witness of the suffering of the Other, to use another metaphor by Lévinas, this is a thorn stuck in the flesh." Dorota Głowacka, "Znikające ślady: Emmanuel Lévinas, literackie świadectwo Idy Fink i sztuka Holokaustu," Literatura na Świecie 1-2 (2004), 115.

${ }^{64}$ Ibid. 
extremely useful. According to this philosopher, a testimony must allow literariness, which is excluded from its boundaries, so as to feed on it as a parasite. A testimony is thus always "haunted" by the symptom of fiction, of perjury, and of a lie; it stays within a permeable, fluctuating border between fictionality and testimoniality in the court and documentary meanings. ${ }^{65}$ It can be thus concluded that the discourse of memory, based both on facts and on fiction, on what is objective and what is idiosyncratic, and which occupies so much space in Drndić's works, is used to achieve justice, to raise what is hidden from the murky depths to the surface; thus it ultimately appears in the service of the future which-if it wants to remain healthy-should face the difficult and often traumatic past.

Translated by Izabela Dąbrowska

Sabina Giergiel

University of Opole sgiergiel@uni.opole.pl

${ }^{65}$ Ubertowska, Holokaust: Auto(tanato)grafie, 46. 